\title{
PREZYDENT RZECZYPOSPOLITEJ POLSKIEJ JAKO ŚWIADEK W POSTĘPOWANIU KARNYM
}

\section{WSTĘP}

Choć waga refleksji nad konstytucyjnym modelem odpowiedzialności władzy publicznej nie budzi współcześnie wątpliwości ${ }^{1}$, to jednak - wśród ogromu prac dotyczących tego zagadnienia - próżno szukać kompleksowych publikacji dotyczących powszechnych form prezydenckiej odpowiedzialności ${ }^{2}$. Doktryna bowiem, skupiając swoje rozważania na - wyłaniajaccym się z art. 145 Konstytucji ${ }^{3}$ - obrazie odpowiedzialności karnej i konstytucyjnej, pomija szczegółową charakterystykę pozostałych form jego prawnej odpowiedzialności. Dlatego niniejszy artykuł zamierza częściowo wypełnić tę lukę i zajać się zagadnieniem statusu Prezydenta RP jako świadka w postępowaniu karnym. Niemniej skupi się nie tylko na scharakteryzowaniu jego podstawowych obowiązków procesowych, lecz także zarysowaniu obrazu odpowiedzialności głowy państwa za ich niewłaściwe wykonywanie. I choć wydawać się może, że waga niniejszych rozważań sprowadza się do rozwiązania drugoplanowego problemu ustrojowego, to jednak wniosek ten pozostaje daleko idącym uproszczeniem. Artykuł wpisuje się w dyskurs na temat podległości piastuna prezydenckiego urzędu prawu powszechnie obowiąującemu i dlatego też jest głosem w debacie o miejscu odpowiedzialności w katalogu podstawowych wartości Konstytucji.

W świetle powyższych założeń punktem wyjścia zarysowywanych rozważań będzie ogólna refleksja nad istotą immunitetu. Odczytane w tym zakresie wnioski - jako teoretyczna podstawa niniejszego artykułu - uzasadnić maja przyjęte w jej ramach szczegółowe dyrektywy interpretacyjne. Wciąż bowiem sporna wydaje się dopuszczalność rekonstruowania immunitetu na podstawie ogólnych wzorców ustrojowych czy konstytucyjnych zadań określonych orga-

${ }_{1}$ Zob. J. Repel, Trybunat Stanu a wymogi praworzqdności socjalistycznej, w: Z. Świda-Łagiewska (red.), Trybunat Stanu w PRL, Warszawa 1983, s. 75 i n.

${ }^{2}$ Mianem tym określam te z prawnych form odpowiedzialności, które nie są związane z realizacją prezydenckich powinności ustrojowych, a nadto zasady ich egzekwowania nie zostały wyraźnie określone przez prawodawcę. Chodzi więc m.in. o odpowiedzialność cywilna, administracyjna, podatkową czy odpowiedzialność za wykroczenia itp.

${ }^{3}$ Konstytucja Rzeczypospolitej Polskiej z 2 kwietnia 1997 r., Dz. U. 1997, Nr 78, poz. 483 ze zm. 
nów ${ }^{4}$. Następnie poruszono kwestię dopuszczalności wezwania Prezydenta RP na świadka w postępowaniu karnym. Analiza tego problemu ma bowiem charakter pierwotny w stosunku do ewentualnych form prezydenckiej odpowiedzialności, dlatego że fakultatywność stawiennictwa wyklucza traktowanie o odpowiedzialności za niewłaściwą realizację jego obowiązków procesowych. W kontekście odczytanych w tym zakresie wniosków rozważania skoncentruja się na opisie trybu przesłuchiwania Prezydenta RP jako źródła dowodowego. Z uwagi jednak na ograniczone ramy niniejszego artykułu fragment ten zostanie zredukowany do wskazania najważniejszych różnic $\mathrm{w}$ porównaniu z „zwykłym” trybem przeprowadzania dowodu z zeznań świadków. Jednakże stworzony $\mathrm{w}$ ten sposób osobliwy wzorzec prezydenckiego postępowania pokaże klarowne podstawy jego odpowiedzialności. Wykorzystanie zaś odczytanych w tym zakresie konkluzji pozwoli skonstruować niezbędny „fundament” analizy dopuszczalności stosowania kar porządkowych wobec urzędującego Prezydenta RP.

Status Prezydenta RP jako świadka w postępowaniach prawnych był już przedmiotem zainteresowania nauk prawnych. Niemniej fundamentalna w tym zakresie praca Krzysztofa Knoppka ${ }^{5}$ często pozostaje nazbyt ogólnikowa dla praktycznego zastosowania zawartych w niej konkluzji. Podobnie też ocenić należy prace tych przedstawicieli doktryny, którzy - rozważając zagadnienia uprawnień sejmowych komisji śledczych - traktowali o dopuszczalności stosowania przez nie kar porządkowych ${ }^{6}$. Zawarte w ich zakresie rozważania - znacznie determinowane przez niedookreślony mechanizm odpowiedniego stosowania Kodeksu postępowania karnego ${ }^{7}$ - nie muszą być bowiem relewantne na gruncie sensu stricto k.p.k. Dlatego też choć sformułowanie problemu prawnego niniejszych rozważań nie wydaje się podejściem innowacyjnym, to jednak przyznać należy dotychczasowy, rzeczywisty brak pogłębionej nad nim refleksji.

\section{IMMUNITET - ANALIZA KONSTRUKCJI}

Teoretyczna formuła immunitetu stanowi bezpośrednia determinantę zakresu i podstaw odpowiedzialności jej beneficjentów. Niejednolite rozumienie jej istoty - przejawiające się zwłaszcza w różnorodnych sposobach jej definiowania - sprawia jednak, że wciąż sporne pozostają liczne z elementów

${ }^{4}$ Por. D. Dudek, Autorytet Prezydenta a Konstytucja Rzeczypospolitej Polskiej, Lublin 2013, s. 72; A. Chorążewska, Model prezydentury w praktyce politycznej po wejściu w życie Konstytucji $R P z 1997$ r., Warszawa 2008, s. 256 i n.

${ }^{5}$ Por. K. Knoppek, Przestuchanie Prezydenta Rzeczypospolitej Polskiej jako świadka w postepowaniu sqdowym, „Ruch Prawniczy, Ekonomiczny i Socjologiczny” 25, 2002, z. 1, s. 53-56.

${ }^{6}$ Por. P. Sarnecki, Opinia w sprawie możliwości przestuchania Prezydenta Rzeczypospolitej Polskiej przez sejmowa komisję śledczq, „Przegląd Sejmowy” 60, 2004, z. 1, s. 87-88.

${ }^{7}$ Ustawa z 6 czerwca 1997 r. - Kodeks postępowania karnego, Dz. U. 2016, poz. 1749 ze zm. (dalej jako: k.p.k.). 
składających się na obraz prawnej odpowiedzialności podmiotów w tym zakresie uprzywilejowywanych. Powyższa różnorodność poglądów oddziałuje też na trudności w definiowaniu formuły prezydenckiego immunitetu, w tym prawnych konsekwencji jego obowiązywania. Dlatego punktem wyjścia niniejszych rozważań jest wskazanie przyjmowanej, teoretycznoprawnej istoty immunitetu.

W tym zakresie przyjmuję za Sławomirą Wronkowską i Zygmuntem Ziembińskim, że immunitet stanowi pochodną sytuację prawną danego podmiotu, która przejawia się w tym, iż jest on „[...] zwolniony od podległości kompetencji podmiotu $A$, podczas gdy inne podmioty kompetencji tej podlegają" . I choć tradycyjnie opisywana konstrukcja ujmowana jest w kontekście instytucji nauk penalnych $^{9}$, to jednak jej normatywna formuła może oddziaływać również na inne formy odpowiedzialności ${ }^{10}$. Przykładowo wyłączenie określonych podmiotów spod kompetencji organów podatkowych wpływa na dopuszczalność egzekwowania ich odpowiedzialności podatkowej. Z kolei przyjęcie, że dany podmiot, chociaż nie podlega jurysdykcji sądów powszechnych, wyłącza możliwość stosowania wobec niego m.in. kar porządkowych. Powyższe rozumienie immunitetu wyraźnie przy tym koresponduje z etymologicznym ujęciem jego łacińskiego źródłosłowu (łac. immunitas), który wprost oznaczał wolność od określonych obowiązków ${ }^{11}$.

Przy tym zaznaczyć należy, że także przyjęta konstrukcja teoretyczna immunitetu - choć z natury swej nader uniwersalna - nie ma charakteru jednolitego. Nie budzi bowiem wątpliwości jej podział na immunitety formalne i materialne, których podstawą rozróżniania zdaje się charakter norm, spod których egzekwowania wyłączany jest podmiot immunowany. W przypadku struktur o formalnoprocesowym zabarwieniu uprawniony wyłączony jest spod podległości normom sankcjonującym bądź też normom określającym zakres jurysdykcji określonych organów ${ }^{12}$. Sprawia to, że choć formalnie jego czyny realizują znamiona przestępstw, wykroczeń czy innych czynów bezprawnych, to niedopuszczalne - ze względu na istnienie przeszkody procesowej - jest wszczęcie i prowadzenie właściwego w tym zakresie postępowania prawnego. Zaznaczyć przy tym należy, że - w zależności od decyzji prawodawcy - istota wspominanej przeszkody procesowej może mieć charakter trwały lub czasowy, co pozwala na wtórne wyróżnienie konstrukcji immunitetów trwałych lub czasowych. Natomiast w przypadku immunitetów materialnych wyłączona zostaje możliwość egzekwowania samych norm sankcjonowanych - wszak w przedmiotowych sytuacjach immunitet jest nie tyle ujemna przesłanka procesowa, ile okolicznością wyłączającą bezprawność podejmowanego zachowania, co wyklucza racjonalność traktowania o naruszeniu zarysowanej katego-

${ }^{8}$ S. Wronkowska, Z. Ziembiński, Zarys teorii prawa, Poznań 2001, s. 108; por. też. P. Grzegorczyk, Immunitet państwa w postepowaniu cywilnym, Warszawa 2010, s. 34-35.

9 W. Michalski, Immunitety $w$ polskim procesie karnym, Warszawa 1970, s. 9.

10 Zob. K. Grajewski, Immunitet parlamentarny w prawie polskim, Warszawa 2001, s. 14.

11 Zob. J. Korpanty (red.), Mały słownik tacińsko-polski, Warszawa 2007, s. 315, s.v. immunitas, za: K. Grajewski, op. cit., s. 11.

12 Por. B. Janusz-Pohl, Immunitety w polskim postepowaniu karnym, Warszawa 2009, s. 28. 
rii norm. Równolegle nie można również zapominać o wyróżnianej w doktrynie konstrukcji immunitetu opisywanej mianem przywileju nietykalności, który - wyłamując się niejako z dychotomicznego podziału na immunitety formalne i materialne - zasadniczo wyłącza dopuszczalność zatrzymania podmiotu immunowanego.

Powyższy szkic istoty immunitetu - choć z uwagi na ramy niniejszego artykułu nie jest jego pełna analiza - podkreśla konieczność jego traktowania jako wyjątku od ogólnych zasad podległości kompetencyjnej. Perspektywa ta oddziałuje zaś na właściwą egzegezę przedmiotowej konstrukcji. Po pierwsze, wyłącza możliwość domniemywania immunitetu ${ }^{13}$. Po drugie zaś, zakazuje wykładni rozszerzajacej zarówno podmiotowego, jak i przedmiotowego zakresu immunitetu ${ }^{14}$. Obie dyrektywy nie powinny przy tym budzić wątpliwości, gdyż wynikają one wprost z ogólnych zasad wykładni wyjątków - każdorazowo bowiem w kontekście immunitetów wskazuje się, że stanowią one przede wszystkim wyjątek od bezwzględnego obowiązku respektowania konstytucyjnej zasady równości obywateli wobec prawa ${ }^{15}$. Zaznaczyć też należy, że tożsame wskazówki interpretacyjne odnaleźć można w orzecznictwie zarówno $\mathrm{SN}^{16}$, jak i TK, który nader wyraźnie wskazuje, że w związku z charakterem immunitetów właściwe „[...] regulacje immunitetowe muszą być interpretowane według zasad wykładni wyjątków, co m.in. wyklucza stosowanie wykładni rozszerzającej”17. Dlatego też ich przyjęcie nie powinno budzić wątpliwości.

\section{WEZWANIE PREZYDENTA RP NA ŚWIADKA W POSTECPOWANIU KARNYM}

Jednym z podstawowych problemów związanych z udziałem Prezydenta RP w postępowaniach prawnych pozostaje kwestia dopuszczalności jego wezwania w charakterze źródła dowodowego. Chociaż bowiem prawodawca wyraźnie nie uprzywilejował sytuacji prawnej piastuna prezydenckiego mandatu, to jednak - zdaniem części doktryny - jego szczególną w tym zakresie pozycję wyprowadzić można z szeregu norm konstytucyjnych, w tym zwłaszcza określających zasady jego odpowiedzialności czy rolę jako najwyższego przedstawiciela $\mathrm{RP}^{18}$. Część autorów zauważa bowiem, że w każdej z obowiązujących ustaw procesowych - w tym również w k.p.k. - trudno jest odnaleźć konkretny przepis wyrażający normę kompetencyjną uprawniającą właściwe organy

${ }_{13}$ Por. A. Szmyt, Opinia w sprawie możliwości przesłuchania Prezydenta Rzeczypospolitej Polskiej przez sejmowa komisję śledczq, „Przegląd Sejmowy” 60, 2004, z. 1, s. 86.

${ }^{14}$ Por. T. Dukiet-Nagórska, Kilka uwag o karnomaterialnych aspektach immunitetu parlamentarnego, „Gdańskie Studia Prawnicze” 19, 2008, s. 101; W. Michalski, op. cit., s. 30.

15 Por. B. Banaszak, Prawo konstytucyjne, Warszawa 2008, s. 408.

16 Wyrok SN z 13 kwietnia 2007 r., I CSK 31/07, OSNC 2008, nr 5, poz. 48.

17 Wyrok TK z 28 listopada 2001 r., K 36/01, OTK 2001, nr 8, poz. 255.

18 Por. J. Trzciński, Opinia w sprawie możliwości przestuchania Prezydenta Rzeczypospolitej Polskiej przez sejmowa komisję śledczq, „Przegląd Sejmowy” 60, 2004, z. 1, s. 66. 
do wezwania Prezydenta RP jako świadka w toczącym się postępowaniu. Jak bowiem wskazuje TK, błędne jest jej upatrywanie w normatywnym obrazie art. $177 \S 1$ k.p.k. ${ }^{19}$ Prawidłowa egzegeza powyższej regulacji prowadzić może bowiem jedynie do wniosku, że każdy wezwany zobowiązany jest do stawienia się, lecz nie do tego, że właściwe organy wezwać moga każdego ${ }^{20}$. Dlatego też szczegółowy katalog podmiotów podległych kompetencji organów procesowych winno się konstruować jedynie na podstawie innych norm systemu prawnego. Ich zaś interpretacja prowadzi niewątpliwie do wniosku, że „[...] Prezydent RP to nie jest »każda osoba «; jest to osoba wyjątkowa (jedyna) w państwie, będąca piastunem najwyższego, niezależnego od władzy ustawodawczej i władzy sądowniczej, urzędu prezydenckiego" ${ }^{21}$. Wspominana niezależność - oddziałując na egzegezę innych przepisów - wyłącza zaś istnienie jakichkolwiek przejawów podległości kompetencyjnej głowy państwa względem innych organów władzy publicznej, w tym także organów władzy sądowniczej ${ }^{22}$. W konsekwencji - zgodnie z prezentowanym poglądem - niedopuszczalne jawi się wzywanie Prezydenta RP na świadka w postępowaniu karnym. Zarysowaną interpretację-zdaniem jej zwolenników - wzmacnia art. 145 Konstytucji, który określa w swojej warstwie normatywnej zakres jurysdykcji TS, prawodawca zdaje się wyposażać Prezydenta RP w „szczególny immunitet”, którego konstrukcja wyłącza jakiekolwiek przejawy kognicji sądów powszechnych ${ }^{24}$.

W tym zakresie warto jednak zaznaczyć, że przedwojenny prawodawca - zdając sobie sprawę z doniosłości regulacji przedmiotowego zagadnienia nader odmiennie określił rolę Prezydenta RP w postępowaniach sądowych. Zarówno na gruncie znowelizowanego w 1932 r. Kodeksu postępowania cywilnego ${ }^{25}$, jak i Kodeksu postępowania karnego z 1928 r. ${ }^{26}$, przewidział on bowiem jasną regulację dopuszczająca przesłuchanie urzędującego Prezydenta RP. Pomijając $\mathrm{w}$ tym miejscu analizę racjonalności takiego rozstrzygnięcia, warto zauważyć, że jego obraz oznacza, że „[...] przedwojenny ustawodawca uznawał za w pełni dopuszczalne, iż urzędujący Prezydent może zostać przez sąd powo-

19 Por. wyrok TK z 22 września 2006 r., U K 4/06, OTK 2006, nr 8A, poz.109 - choć tezę tę TK oparł na art. 11 ust. 1 ustawy z 21 stycznia 1999 r. o sejmowej komisji śledczej (Dz. U. Nr 35, poz. 321 ze zm.), to jej charakter wydaje się uniwersalny; por. też: postanowienie SA w Warszawie z 21 sierpnia 2007 r., II AKz 478/07, Lex nr 318343.

20 Por. wyrok TK z 22 września 2006 r., U K 4/06.

21 J. Mordwiłko, Opinia w sprawie możliwości przesłuchania Prezydenta Rzeczypospolitej Polskiej przez sejmowa komisję śledcza, „Przegląd Sejmowy” 60, 2004, z. 1, s. 83.

22 Jak zauważa J. Mordwiłko - powołując się na francuską praktykę ustrojową - niedopuszczalność wzywania urzędującego Prezydenta RP na świadka nie powinna budzić wątpliwości, gdyż „[...] jego status jest bowiem wyjątkowy, gdyż wybrał go bezpośrednio naród jako gwaranta trwałości państwa" (idem, op. cit., s. 81).

${ }_{23}$ W. Sokolewicz, Opinia $w$ sprawie możliwości przesłuchania Prezydenta Rzeczypospolitej Polskiej przez sejmowa komisję śledczq, „Przegląd Sejmowy” 60, 2004, z. 1, s. 70; por. D. Dudek, op. cit., s. 72 .

${ }^{24}$ J. Mordwiłko, op. cit., s. 80; por. też B. Janusz-Pohl, op. cit., s. 106-107.

${ }^{25}$ Rozporządzenie Prezydenta Rzeczypospolitej z 29 listopada 1930 r. - Kodeks postępowania cywilnego, Dz. U. R.P. Nr 112, poz. 934.

${ }_{26}$ Rozporządzenie Prezydenta Rzeczypospolitej z 19 marca 1928 r. - Kodeks postępowania karnego, Dz. U. R.P. Nr 78, poz. 443. 
łany na świadka w procesie cywilnym lub karnym" ${ }^{27}$. I choć powyższa refleksja ma przede wszystkim charakter historyczny, to jednak niesie za sobą szereg konsekwencji. Zdaniem wielu przedstawicieli doktryny oznacza ona bowiem, że - wobec trwałości istoty prezydenckiego urzędu - również „[...] obecnie dopuszczalne jest powołanie Prezydenta RP na świadka w sprawie cywilnej lub karnej”28. Zwolennicy zarysowanej konkluzji podkreślają przy tym, że w czynności wezwania w charakterze świadka nie chodzi „[...] o kwestie związane ze sprawowaniem urzędu przez Prezydenta ani tym bardziej o ingerencje władzy sądowniczej w tę dziedzinę, lecz jedynie o przesłuchanie obywatela piastującego w danym momencie urząd Prezydenta" ${ }^{29}$. Dlatego też wszelkie w tym zakresie uprzywilejowanie głowy państwa wydaje się, ich zdaniem, nieuzasadnione. Nadto jak zauważa Stanisław Hoc, prawidłowy „[...] jest pogląd, że "sprawowanie urzędu nie może stanowić przesłanki uzyskiwania przywilejów nieokreślonych expressis verbis w normach prawnych", dlatego też wezwanie prezydenta $\mathrm{w}$ charakterze świadka jest $\mathrm{w}$ istocie wezwaniem obywatela w charakterze świadka i „nie ma odniesienia do jego kompetencji określających zakres władzy” ${ }^{30}$. Nie można bowiem zapominać, że „[...] prezydent jest zobowiązany wypełniać obowiązki spoczywające na każdym obywatelu RP”31.

Dlatego wobec zarysowanej różnorodności poglądów dotyczących dopuszczalności wezwania Prezydenta RP na świadka konieczna wydaje się własna refleksja nad przedmiotowym zagadnieniem. Jej niezbędnym punktem wyjścia pozostaje zaś rozróżnienie dwóch płaszczyzn prezydenckiej działalności. Pierwsza - określana mianem prywatnej - odnosi się do możliwości wezwania w charakterze świadka osoby fizycznej, która - co pozostaje kwestią drugorzędną dla racjonalności wezwania - w danym momencie pełni akurat funkcję głowy państwa. Druga zaś - nazywana mianem urzędowej - sprowadza się do dopuszczalności wezwania w charakterze świadka Prezydenta RP - niezależnie od tego, kto $\mathrm{w}$ danym momencie sprawuje ten urząd. Chodzi więc o sytuacje, w których przesłuchanie Prezydenta RP pełniłoby funkcję zbliżona do przesłuchania organu określonej jednostki organizacyjnej. Z uwagi jednak na status Prezydenta RP, a także specyfikę jurysdykcji karnej (odnoszacej się wyłącznie do odpowiedzialności osób fizycznych), trudno jest sobie wyobrazić realną sytuację, w której wezwanie w tym charakterze mogłoby nastapić. Dlatego też dopuszczalność wezwania w charakterze świadka Prezydenta $\mathrm{RP}$ - w zakresie dotyczacym płaszczyzny urzędowej - pozostanie z uwagi na swą abstrakcyjność poza zakresem dalszych rozważań.

Pamiętając więc o zakresie niniejszych przemyśleń, należy zwrócić uwagę, że choć rzeczywiście trudno jest wskazać przepis, którego egzegeza uprawnia

${ }^{27}$ K. Knoppek, op. cit., s. 53.

${ }^{28}$ Ibidem.

${ }^{29}$ B. Banaszak, Konstytucja Rzeczypospolitej Polskiej, Warszawa 2009, s. 779-780; por. A. Chorążewska, op. cit., s. 257 i n.

${ }^{30}$ S. Hoc, Prezydent RP jako świadek w postepowaniu sqdowym, w: J. Skorupka (red.), Rzetelny proces karny. Księga jubileuszowa Profesor Zofii Świdy, Warszawa 2009, s. 382.

31 J. Ciapała, Zagadnienie odpowiedzialności prawnej Prezydenta Rzeczypospolitej Polskiej, „Przegląd Sejmowy” 71, 2005, z. 6, s. 118. 
do wezwania Prezydenta RP w charakterze świadka, to w systemie prawnym norma taka z pewnością obowiązuje. O jej istnieniu wnioskować można bowiem z szeregu norm systemu postępowania karnego, w tym zwłaszcza konstrukcji art. $581 \S 1$ k.p.k. Ów przepis - wskazując wyraźne ograniczenie kompetencji organów postępowania karnego do wzywania w charakterze świadka określonych podmiotów - traciłby bowiem swój sens normatywny w przypadku, gdy w systemie prawnym brak by było normy generalnie dopuszczającej wzywanie każdego w charakterze świadka. Niemniej racjonalny prawodawca nie tworzy jednostek redakcyjnych, których istnienie nie posiada uzasadnienia normatywnego, a sytuacja taka zaistniałaby, gdyby uznać, że w systemie prawnym brak normy generalnie dopuszczającej wzywanie każdego w charakterze świadka. Nadto obraz przedmiotowej regulacji wyraźnie wskazuje, że wszelkie wyjątki od analizowanej kompetencji właściwych organów prawodawca wyraża expressis verbis. Chociaż bowiem podobne ograniczenie - związane z immunitetem dyplomatycznym - można by było wyprowadzić z przepisów Konstytucji lub norm prawnomiędzynarodowych, w tym zwłaszcza art. 31 Konwencji wiedeńskiej o stosunkach dyplomatycznych ${ }^{32}$, to jednak prawodawca i tak nader klarownie potwierdził obowiązywanie takiego wyjątku w postępowaniu karnym. Dlatego - domniemując konsekwencje w działaniach prawodawcy uznać należy, że gdyby podobne uprzywilejowanie chciałby odnieść również do Prezydenta RP, to wyraźnie by na to wskazywał. Takiego zaś wskazania próżno szukać w aktualnym obrazie systemu prawnego. Jak słusznie zauważa bowiem Monika Zbrojewska: „[...] w kodeksie postępowania karnego nie przewidziano jakichkolwiek przeszkód prawnych odnośnie do wzywania i przesłuchiwania w charakterze świadka osoby sprawującej jakąolwiek funkcję czy urząd bądź piastującą określone stanowisko" ${ }^{3}$. Podobnego ograniczenia nie da się również bezspornie wyprowadzić z przepisów Konstytucji ${ }^{34}$. Pamiętać bowiem należy, że art. 145 Konstytucji - ograniczając jurysdykcję sądów powszechnych - odnosi się wyłącznie do odpowiedzialności za przestępstwo bądź delikt konstytucyjny. Tym samym brak podstaw, aby na tej podstawie całkowicie i zupełnie wyłączyć właściwość sądów powszechnych. Prawidłowość powyższej argumentacji wzmacniają też przytoczone wcześniej refleksje zwolenników tezy o dopuszczalności wzywania Prezydenta RP, a także zarysowane zasady wykładni immunitetów, które zakazują ich domniemywania. Dlatego przyjęcie konkluzji o dopuszczalności wzywania go na świadka nie powinno budzić wątpliwości.

Omawiając sygnalizowane zagadnienie, należy także zwrócić uwagę na kilka bardziej szczegółowych problemów. W pierwszej kolejności zaznaczenia więc

${ }^{32}$ Konwencja wiedeńska o stosunkach dyplomatycznych sporządzona w Wiedniu z 18 kwietnia 1961 r., Dz. U. z 8 września 1965 r.

${ }^{33}$ M. Zbrojewska, Karnoprocesowe aspekty postepowania przed komisja śledcza, „Przegląd Sejmowy" 60, 2004, z. 1, s. 30.

${ }^{34}$ Por. analogiczne rozważania dotyczące Prezesa NBP: Z. Gromek, Glosa do postanowienia Sadu Apelacyjnego $w$ Warszawie z 21 sierpnia 2007 r. (sygn. akt II AKz 478/07) oraz postanowienia Sadu Okręgowego w Warszawie z dnia 16 października 2007 r. (sygn. akt VIII Ko 9/07), „Przegląd Sejmowy” 88, 2008, z. 5, s. 198. 
wymaga obraz praktyki przesłuchiwania głowy państwa ${ }^{35}$. Przyjęło się bowiem, że składa ona zeznania w postępowaniach prawnych po uprzednim uzgodnieniu miejsca i terminu przesłuchania. I choć teoretycznie procedura taka nie musi być zachowana, to jednak - z uwagi na ryzyko niestawiennictwa na wyznaczone posiedzenie piastuna prezydenckiego mandatu związane $\mathrm{z}$ ogromem jego obowiazków służbowych ${ }^{36}$ - racjonalne wydaje się kontynuowanie zarysowanej praktyki. Znajduje ona bowiem silne uzasadnienie w obowiązującej zasadzie szybkości postępowania oraz - w wyłaniającym się z art. $171 \S 7$ k.p.k. - obowiązku zabezpieczenia swobody wypowiedzi świadka. Wszak nietrudno sobie wyobrazić, że w sytuacji zbiegu obowiązków procesowych i służbowych zachowanie przedmiotowej swobody mogłoby być realnie zagrożone.

Nadto warto zauważyć, iż powyższa konkluzja pozostaje aktualna zarówno w odniesieniu do kompetencji organów postępowania przygotowawczego, jak i sadów powszechnych. Mimo to słuszne wydaje się postulowanie, by - z uwagi na tożsamość Ministra Sprawiedliwości i Prokuratora Generalnego - przesłuchanie głowy państwa w postępowaniu przygotowawczym odbywało się zawsze przed sądem w trybie art. $316 \S 3$ k.p.k. Istnieje bowiem ryzyko, iż w późniejszym postępowaniu sądowym ponowne przesłuchanie będzie znacznie utrudnione lub wręcz niemożliwe. Jednocześnie wydaje się, iż proponowany tryb przesłuchiwania przyczyni się do wzmocnienia - wyłaniajacego się z Konstytucji - obrazu relacji między Prezydentem RP a Radą Ministrów. Analiza jej przepisów - w tym zwłaszcza art. 141, art. 154 ust. 1 oraz art. 155 - prowadzi bowiem do wniosku, że to Prezydent RP winien być inicjatorem kontaktów z Radą Ministrów i jej członkami. Ów klarowny obraz ustrojowy mógłby zaś znacząco się zachwiać, gdyby Minister Sprawiedliwości - działając jako Prokurator Generalny - wzywał Prezydenta RP jako świadka w związku z jakimkolwiek toczącym się postępowaniem karnym.

\section{TRYB PRZESLUCHIWANIA PREZYDENTA RP}

Przesłuchiwanie Prezydenta RP jako świadka w toczacym się postępowaniu karnym podzielić można na dwa etapy. W ramach czynności składających się na pierwszy z nich wyodrębnić zaś można czynności związane z uzyskiwaniem danych osobowych świadka oraz udzielaniem niezbędnych pouczeń. Natomiast drugi etap - określany mianem przesłuchania właściwego - składa się z czynności zmierzających bezpośrednio „[...] do wydobycia od świadka środków dowodowych mających znaczenie dla rozstrzygnięcia sprawy" ${ }^{37}$. Pamiętając o powyższym rozróżnieniu, należy zwrócić uwagę, że ogólny zarys trybu przesłuchiwania Prezydenta RP pozostaje tożsamy jak w przypadkach przesłuchiwania innych podmiotów ${ }^{38}$. Dlatego w ramach niniejszego artykułu wystarczy podkreślić występujące w tym zakresie różnice i wątpliwości.

${ }^{35}$ Por. Komorowski przed sadem. Przesłuchanie głowy państwa w procesie Wojciecha Sumlińskiego, <www.wpolityce.pl> [dostęp: 20.12.2017].

${ }^{36}$ K. Knoppek, op. cit., s. 55.

37 J. Zagrodnik, Metodyka pracy obrońcy i petnomocnika w sprawach karnych i karnych skarbowych, Warszawa 2016, s. 271.

38 Por. K. Knoppek, op. cit., s. 55. 
Po pierwsze, należy zwrócić uwagę na problem składania przysięgi przez Prezydenta RP jako świadka. Zastanawiające jest bowiem, czy głowa państwa może - analogicznie do sytuacji prawnej stałych biegłych sądowych - nie składać przyrzeczenia w trybie art. $188 \S 1$ k.p.k., lecz powołać się na przysięgę składana przed Zgromadzeniem Narodowym. Z jednej bowiem strony fakultatywność przyrzeczenia i realny brak jakichkolwiek dodatkowych skutków prawnych w przypadku jego złożenia uzasadniaja powyższą zastępowalność. Wydaje się też, iż z roty prezydenckiego ślubowania wyprowadzić można nawet szersze powinności niż te wynikające $\mathrm{z}$ karnoprocesowej instytucji przyrzeczenia. Z drugiej jednak strony dopuszczalność takiego zastępowania traktować należy w kategoriach szczególnego immunitetu - co wyłącza możliwość jego domniemywania. Ów argument wydaje się przy tym przesądzać o bezwzględnym charakterze karnoprocesowego przyrzeczenia - wyklucza możliwość jego zastępowania przez powołanie się na treść prezydenckiej przysięgi.

Po drugie, warto rozważyć kwestie konieczności i sposobu dowodzenia faktu sprawowania urzędu. Okoliczność ta bowiem może znacząco wpływać na tryb i zasady jego przesłuchiwania. Dlatego też wydaje się, że ustalenie tej okoliczności nie powinno opierać się jedynie na oświadczeniu świadka. Niemniej słuszne też jest przyjęcie, że nie wymaga ona prowadzenia przez świadka szczególnej inicjatywy dowodowej, gdyż fakt ogłaszania wyników wyborów w „Dzienniku Ustaw” czyni z nich fakt objęty notoryjnością powszechna, co - w rozumieniu art. 168 k.p.k. - uzasadnia odstapienie od prowadzenia w ich zakresie szczegółowego postępowania dowodowego.

W kwestii czynności przesłuchania właściwego należy zwrócić przede wszystkim uwage na obowiązywanie w tym zakresie szczególnych zakazów dowodowych. Pierwszy z nich odnosi się do możliwości przesłuchania piastuna prezydenckiego urzędu na okoliczności objęte ochroną informacji niejawnych o klauzuli „tajne” bądź „ściśle tajne”. Chociaż bowiem brak normy wyłączającej bezwzględnie możliwość składania zeznań w tym zakresie, to regulacja art. $179 \S 1$ k.p.k. faktycznie wyklucza możliwość ich przekazywania. Wszak w systemie prawnym brak jakiegokolwiek organu kompetentnego do zwolnienia Prezydenta RP z obowiązku zachowania tajemnicy. Równolegle też zaznaczyć należy, że „Brak jest też jakiegokolwiek podstawy prawnej, aby sąd orzekajacy zwracał się do Sejmu lub Zgromadzenia Narodowego z wnioskiem o zwolnienie Prezydenta od obowiązku zachowania tajemnicy"39. Sprawia to, że w przypadku przesłuchiwania głowy państwa tradycyjnie względny zakaz dowodowy przekształca się $\mathrm{w}$ bezwzględne wyłączenie dopuszczalności jego przesłuchiwania na rzeczone okoliczności. I choć podnosić można, że - w związku z zakazem prowadzenia wykładni rozszerzającej zakazów dowodowych ${ }^{40}-$ charakteru zakazów dowodowych nie powinno się w ten sposób domniemywać, to jednak podkreślić należy, iż równie niedopuszczalne jawi się uzupełnianie luk działalności prawodawcy przez określone domniemania kompetencyjne.

39 Ibidem.

${ }^{40}$ A. Gaberle, Dowody w sadowym procesie karnym. Teoria i praktyka, Warszawa 2010, s. 311 . 
Natomiast drugi ze specyficznych zakazów dowodowych wydaje się odnosić do - wyłaniającego się z art. 183 k.p.k. - prezydenckiego uprawnienia do odmowy odpowiedzi na pytanie. Wszak w związku ze osobliwością prezydenckich form odpowiedzialności otwarta pozostaje kwestia obowiazzywania uprawnienia do odmowy odpowiedzi na pytanie w sytuacji, gdy jej udzielenie mogłoby narazić głowę państwa na odpowiedzialność konstytucyjna. W tym zakresie słuszne wydaje się przyjęcie, że zarysowane uprawnienie obowiązuje. Chociaż nie zostało ono wyrażone w k.p.k., to jednak jego obraz odczytać można z wykładni licznych standardów konstytucyjnych i prawnomiędzynarodowych, w tym zwłaszcza z prawa do rzetelnego procesu lub prawa do obrony. Jak zauważa się w doktrynie, reguła nemo se ipsum accusare tenetur winna być zawsze postrzegana jako jedna z podstawowych „[...] gwarancji praw jednostki chroniącej osobę, która nie jest w ogóle uwikłana w proces karny (nie ma statusu oskarżonego) [...]"41. Dlatego też słuszne jest rozszerzenie jej obowiązywania na przypadki odnoszące się do odpowiedzialności konstytucyjnej.

\section{STOSOWANIE KAR PORZĄDKOWYCH WOBEC PREZYDENTA RP}

Aby zrekonstruować zakres odpowiedzialności Prezydenta RP za niewłaściwą realizacje jego podstawowych obowiązków procesowych, należy zwrócić uwagę na brak wyraźnej regulacji powyższego zagadnienia. Fakt ten sugeruje, że właściwa $\mathrm{w}$ tym zakresie odpowiedzialność głowa państwa ponosi przed sądami powszechnymi. Pamiętając bowiem o wyłaniającym się z regulacji ustawowych znaczeniu pojęcia „przestępstwo”, uznawać można, że jurysdykcja TS nie rozciaga się na sprawy związane z prezydencka odpowiedzialnościa porządkowa. Przedmiotowa interpretację potwierdza art. 2 ust. 1 ustawy o Trybunale Stanu ${ }^{42}$, który - określając zakres jurysdykcji TS - jakkolwiek nie wspomina o prezydenckiej odpowiedzialności porządkowej. Nadto także doktryna, traktując o właściwej interpretacji pojęcia „przestępstwo” (obecnego na gruncie art. 145 Konstytucji) często wskazuje, że zakres jego desygnatów obejmuje wyłącznie przestępstwa i wykroczenia ${ }^{43}$. Biorąc więc pod uwagę powyższe konkluzje z obowiązującym zakazem domniemywania immunitetów, nie powinny dziwić poglądy tej części doktryny, która podkreśla, że w czasie przesłuchania Prezydent RP nie tylko w pełni podlega władzy sędziego, lecz także może w tym zakresie ponieść odpowiedzialność porządkowa ${ }^{44}$.

Mimo powyższych argumentów często intuicyjnie przyjmujemy, iż Prezydent RP nie może odpowiadać porządkowo na zasadach ogólnych. Wypły-

${ }^{41}$ R. Koper, Prawo do obrony osoby podejrzanej, „Prokuratura i Prawo” 2016, z. 2, s. 23; por. też W. Jasiński, Prawo do nieobciażania się $w$ procesie karnym w świetle standardów strasburskich, „Prokuratura i Prawo” 2015, z. 7-8, s. 7-35.

${ }^{42}$ Ustawa z 26 marca 1982 r. o Trybunale Stanu, Dz. U. 2002, Nr 101, poz. 925 ze zm. (dalej jako: u.T.S.).

${ }^{43}$ Por. K. Dąbrowski, Odpowiedzialność Prezydenta za wykroczenia, „Przegląd Prawa Konstytucyjnego" 35 , 2017, z. 1, s. 110 i n.

${ }^{44}$ Por. K. Knoppek, op. cit., s. 55. 
wajaca $\mathrm{z}$ art. 145 Konstytucji konstrukcja privilegium fori spełnia bowiem swoją rolę jedynie przy uznaniu zupełnej i wyłącznej jurysdykcji TS ${ }^{45}$. Tylko bowiem w ten sposób ustrojodawca może realnie zabezpieczyć majestat Rzeczypospolitej i ustrzec piastuna prezydenckiego urzędu przed nadużywaniem wobec niego środków represyjnych. Dlatego mając na względzie wyłaniający się z art. 285-287 k.p.k. katalog kar porządkowych - obejmujaccy w istocie środki tożsame jak w przypadku przestępstw sensu stricto - trudno jest odnaleźć racjonalne uzasadnienie zróżnicowania przez prawodawcę reżimów egzekucji obu form odpowiedzialności. W konsekwencji konieczna też wydaje się refleksja nad argumentami przemawiajacymi za rozszerzeniem - występującego w art. 145 Konstytucji - pojęcia przestępstwa jako obejmującego wszelkie formy odpowiedzialności represyjnej, w tym także odpowiedzialność porządkową.

Należy rozpocząć od uwagi, że ustrojodawca jakkolwiek nie posługuje się nazwami „odpowiedzialność porządkowa”, „kara porządkowa” itp., niemniej nie wyklucza, by zakres desygnatów konstytucyjnego terminu „przestępstwo” interpretować nader szeroko, tj. jako nazwę obejmującą wszelkie formy odpowiedzialności represyjnej. Interpretacji takiej nie ogranicza przy tym obowiązujący zakaz domniemywania immunitetów czy dyrektywa ograniczająca ich wykładnie rozszerzająca. Trudno bowiem ustalić językowe znaczenie owego terminu, gdy ma ono nieempiryczny charakter, a ustrojodawca nie zostawił wyraźnych wskazówek jego interpretacji. I choć dla określenia właściwego zakresu desygnatów przedmiotowej nazwy można pomocniczo odwoływać się do definicji ustawowych, to jednak ów sposób rozumienia nie może wiązać przy wykładni terminów konstytucyjnych. Przeciwne twierdzenie jawiłoby się niedopuszczalne z perspektywy hierarchii źródeł prawa. Dlatego też uznać należy, że na gruncie Konstytucji trudno jest odnaleźć przeszkody dla odstapienia od ustawowego zakresu desygnatów nazwy „przestępstwo” na rzecz jej nader szerokiej egzegezy.

W tym miejscu konieczne jest również podkreślenie wspominanej tożsamości istoty kar porządkowych oraz kar kryminalnych. W obu przypadkach możliwe jest bowiem wymierzenie zarówno kar majątkowych (art. 285 k.p.k.), jak i kar polegających na faktycznym pozbawieniu wolności (określanych w art. 287 k.p.k. mianem aresztu). W konsekwencji również skutki prawne ich zastosowania wydają się nader zbliżone, a te w przypadku kar aresztu oraz kary pozbawienia wolności wydają się nader doniosłe. Ich orzeczenie - w obu przypadkach - implikuje bowiem konieczność tymczasowego przejęcia przez Marszałka Sejmu obowiązków Prezydenta RP - co stanowiąc konieczną formułę ograniczenia zasady trójpodziału władzy, pozostaje fundamentalnym argumentem za wyłączeniem w tym zakresie jurysdykcji sądów powszechnych ${ }^{46}$. Wszak racjonalny prawodawca, dostrzegając zbieżne niebezpieczeństwa związane $\mathrm{z}$ istotą określonych sankcji prawnych, winien w tożsamy sposób ograniczyć ryzyko ich zaistnienia.

45 Por. wyrok TK z 21 lutego 2001 r., P 12/00, OTK 2001, nr 3, poz. 47.

${ }_{46}$ Por. K. Dąbrowski, op. cit., s. 119. 
Nie można również zapominać o represyjnym charakterze kar porządkowych. Chociaż bowiem wskazuje się, że ich funkcja „[...] sprowadza się do zabezpieczenia prawidłowego toku postępowania oraz zapewnienia, by było prowadzone bez zbędnej zwłoki, w sposób ciagły, sprawny i zorganizowany" ${ }^{\text {"7 }}$, to jednak nie sposób kwestionować, że „[...] to właśnie represja, a pewnym sensie również i prewencja, stanowią podstawowe cele kar porządkowych" ${ }^{48}$. Zarysowana kwalifikacja wydaje się przy tym nader doniosła. Pamiętając bowiem o orzecznictwie TK - wskazujacym, że w sytuacjach gdy ,[...] celem sankcji jest represja bądź prewencja połaczona z represja, to świadczy to o charakterze "kryminalnym" czynu i o karnym charakterze sankcji" ${ }^{49}$ - niewatpliwie konieczne jest stosowanie we właściwym w tym zakresie postępowaniu prawnym odpowiednich standardów rzetelnego procesu karnego, w tym zwłaszcza podstawowych gwarancji procesowych. Postrzegając zaś privilegium fori jako szczególną gwarancję zachowania rzetelności postępowania, racjonalne jest rozszerzenie jurysdykcji TS również o sprawy w przedmiocie prezydenckiej odpowiedzialności porządkowej. Do takiej interpretacji skłania również wniosek a minori ad minus - skoro TS orzekać może w sprawach przestępstw jako podstawy prezydenckiej odpowiedzialności, to tym bardziej dopuszczalne winno być orzekanie przez niego w sprawach łagodniejszego rodzaju.

Zarysowane argumenty zadaja się uzasadniać rozszerzenie - w drodze egzegezy konstytucyjnego terminu „przestępstwo” - właściwości TS o kompetencje do orzekania w przedmiocie prezydenckiej odpowiedzialności porządkowej. Co prawda orzekanie w tym przedmiocie mogłoby być utrudnione przez brak wyraźnej regulacji zasad procedowania TS, przedmiotowa trudność nie powinna być jednak wystarczającym argumentem dla przeciwnej interpretacji - istniejącą w tym zakresie lukę wypełnić można bowiem przez stosowanie per analogiam regulacji odnoszących się do ogólnych zasad postępowania przed TS. Warto przy tym zauważyć, że ku zbliżonym konkluzjom skłania się także S. Hoc, który wskazuje, że jego zdaniem: „Niepodporządkowanie się obowiązkom procesowym wskazanym w art. 177 § 1 k.p.k. powinno być analizowane w kategoriach naruszenia ustawy, o którym stanowi art. 145 Konstytucji [...]" ${ }^{50}$. Podobnie - choć w kontekście rozważań nad działalnością komisji śledczych - wskazuje również M. Granat ${ }^{51}$. Dlatego też przyjęcie również na gruncie niniejszej pracy konkluzji o wyłącznej jurysdykcji TS w przedmiocie stosowania kar porządkowych wobec głowy państwa nie powinno budzić wątpliwości. Mimo to słuszne jest postulowanie de lege ferenda wyraźnej w tym zakresie regulacji.

${ }^{47}$ J. Kosonoga, System środków dyscyplinujacych uczestników postępowania karnego, Warszawa 2014, s. 34.

${ }^{48}$ M. Szwast, M. Szwed, Konstytucyjne aspekty kar porzadkowych pozbawienia wolności, „Przegląd Legislacyjny” 95, 2016, z. 1, s. 42.

${ }_{49}$ Por. wyrok TK z 1 lipca 2014 r., SK 6/12, OTK 2014, nr 7A, poz. 68.

${ }^{50}$ S. Hoc, op. cit., s. 387.

${ }^{51}$ M. Granat, Opinia $w$ sprawie sktadania zeznań przez Prezydenta RP przed sejmowa komisja śledczq, „Przegląd Sejmowy” 60, 2004, z. 1, s. 112. 


\section{WNIOSKI}

W świetle powyższych rozważań należy uznać, że w aktualnym obrazie systemu prawnego brak spójnej i czytelnej regulacji dotyczącej statusu Prezydenta RP jako świadka w postępowaniu karnym. Z jednej bowiem strony wezwanie głowy państwa polskiego jest w pełni dopuszczalne, z drugiej jednak - może ona, powołując się na konieczność zachowania tajemnicy informacji niejawnych, realnie uchylić się od obowiązku składania zeznań. Dlatego też słuszny wydaje się postulat stworzenie w tym zakresie wyraźnej i zupełnej regulacji - wykluczającej istniejące spory i niejednolitość interpretacji. Sygnalizowane braki legislacyjne wydają się przy tym wpisywać w szeroką tendencję słabości współczesnego systemu, w którym prawodawca - wbrew bogatej historii wyraźnej regulacji zasad odpowiedzialności głowy państwa - zdaje się zapominać o doniosłej roli, jaką odegrać może ich kompleksowa regulacja. Dlatego też przyznać należy rację Dariuszowi Dudkowi, który w krytycznej analizie współczesnej regulacji ustrojowej wskazuje, że idea odpowiedzialności nie stanowi współcześnie naczelnej wartości ustrojowej ${ }^{52}$.

mgr Kamil Dabrowski

Uniwersytet Szczeciński

kamil.dabrowski@usz.edu.pl

\section{PRESIDENT OF THE REPUBLIC OF POLAND AS A WITNESS \\ IN CRIMINAL PROCEEDINGS}

Summary

The article discusses the legal status of the President of the Republic of Poland acting in the capacity of a witness in the course of legal proceedings. Having noted the insufficiency of the current legal regulation, the author begins his research with a detailed analysis of the concept of immunity and the possible legal circumstances which would allow the Head of the Polish state to be summoned as a witness in criminal proceedings. Then, the procedure of questioning the President of the Republic of Poland and the admissibility of imposing penalties on the Head of the State are presented in detail. The conclusion of the discussion is that although the admissibility of summoning the President of the Republic of Poland to witness should be beyond doubt, the shape of the existing regulations continues to hinder the actual use of the source of evidence in question.

${ }^{52}$ D. Dudek, op. cit., s. 69. 


$$
\text { . }
$$

